\title{
Changes in phyto-diversity on Festuca rubra L. - Agrostis capillaris L. grasslands
}

\author{
Mirela CIREBEA $^{1 *}$, Ioan ROTAR ${ }^{1}$, Roxana VIDICAN ${ }^{1}$, Florin PĂCURAR ${ }^{1}$, Anca PLEŞA ${ }^{1}$ and Ovidiu RANTA ${ }^{1}$ \\ ${ }^{1}$ Department of Plant Culture, Faculty of Agriculturre, University of Agriculture Sciences and \\ Veterinary Medicine Cluj-Napoca, România \\ *Corresponding author: cirebea_mirela@yahoo.com \\ Bulletin USAMV series Agriculture 72(2)/2015 \\ Print ISSN 1843-5246; Electronic ISSN 1843-5386 \\ DOI 10.15835/buasvmcn-agr: 11564
}

\begin{abstract}
Diversity is a term no longer alien to any social category (the ordinary peasant political class) and became the main topic in any actual problem. Phytodiversity are in decline and all policies try to focus their attention to this problem. The importance of grassland ecosystems is increasingly exploited demonstrated and changes lately whether political, economic and / or social affects not only the ecosystem but the whole agricultural system in the world especially fertilization. This is the reason why our experience include a study on semi-natural grassland based on combined form of organic and mineral fertilization. The experiment was placed after experimental technique method and includes six different fertilized treatments in four replications. Experiment is establish in Baisoara Commune, Cluj County. The experience includes four variants in three repetitions, which are: V1 - control variant, (unfertilized); V2 - variant fertilizer with $10 \mathrm{t} /$ ha manure; V3 - variant fertilizer with $10 \mathrm{t} / \mathrm{ha}$ manure + 50N25P25K; V4 - variant fertilizer 20 t/ha manure; V5-variant fertilizer with $10 \mathrm{t} /$ ha manure $+100 \mathrm{~N} 50 \mathrm{P} 50 \mathrm{~K}$ and V6-variant fertilized with 100N50P50K. Like is known, mineral fertilization reduce more than organic fertilization the phytodiversity and in our experiment this are very good highlighted. The studied phytocenosis present a Shannon diversity even if large mineral inputs are are provided.
\end{abstract}

Keywords: diversity, fertilization, grasslands, mountains.

\section{INTRODUCTION}

In many other parts of Europe, grasslands on low productive soils have been transformed into forests either by being planted with coniferous trees or by being abandoned (Nillson et al, 2013). This changed management has had a substantial negative effect on flora and fauna, and many species are declining and are on the verge of regional extinction (Mace et al, 2008). Currently various initiatives are undertaken across Europe to develop and assess the potential of biodiversitybased management practices by farmers, industry, researchers and governmental and nongovernmental organizations (Bianchia et al, 2013).

In many industrialized areas of Europe, seminatural grasslands with high biodiversity presents a relictar spread (Stoie, 2011). Global biodiversity is in decline (Baeten et al, 2014), so Target 1 of the Convention of Biodiversity says that by 2020 at the latest, people are aware of the values of biodiversity and the steps they can take to conserve and use sustainably (www.cdi.gov.ro). Festuca rubra L. is a perennial grass very persistent and tolerant to a wide range of ecological conditions (Vázquez de Aldana et al, 2014).Our aims was to determine the floristic composition under the organic, mineral fertilization or combined these two types of fertilization.

\section{MATERIALS AND METHODS}

The experiment was established in 2014in the place "Cross", in Băişoara Commune, Apuseni Mountains, Romania on a Festuca rubra L.- Agrostis capillaris L. grasslands type, at the altitude of 1240 $\mathrm{m}$. It was delimited experimental field to remove any unwanted danger or grazing has been cleaned 
of woody vegetation and rocks. The experience was placed after experimental technique method. The surface of experimental plots is $20 \mathrm{~m}^{2}$. The experience includes four variants in three repetitions, which are: V1 - control variant, (unfertilized); V2 - variant fertilizer with $10 \mathrm{t} /$ ha manure; $\mathrm{V} 3$ - variant fertilizer with $10 \mathrm{t} / \mathrm{ha}$ manure + 50N25P25K; V4 - variant fertilizer 20 t/ha manure; V5-variant fertilizer with $10 \mathrm{t} / \mathrm{ha}$ manure $+100 \mathrm{~N} 50 \mathrm{P} 50 \mathrm{~K}$ and V6-variant fertilized with $100 \mathrm{~N} 50 \mathrm{P} 50 \mathrm{~K}$.

Floristic studies were performed before mowing after scale vegetation interpretation given by Braun-Blanquet (1932).

Cattle and horse manure and also the mineral inputs were applied in early springtime on the plots (in the beginning of March), according to the treatments. he research has been carried out.

\section{RESULTS AND DISCUSSION}

The variant fertilized only with mineral fertilizer reduce the species number despite of variants which were fertilized organic. The combined fertilizer produced also changes in floristic composition (Fig. 1).

Regarding Poaceae family it can be noticed that only when $20 \mathrm{t} / \mathrm{ha}$ manure are applied are decreasing their percent. In all other variants (with $10 \mathrm{t} /$ ha manure, only mineral fertilization or combined this two fertilization) they increase.

The Cyperaceae and Juncaeae family do not present a spectacular evolution and in all variants they decrease their cover, despite Fabaceae family which increase their average in all treatments.

It is known that mineral fertilization decrease Fabaceae family a fact demonstrated by V4 (variant fertilizer $20 \mathrm{t} /$ ha manure), where are the highest coverage degree.

Plants from other botanical families (AFB) after one year decrease in all variants, especially when $100 \mathrm{~N} 50 \mathrm{P} 50 \mathrm{~K}$ is applied (V5).

Regarding phyto-diversity of grasslands it can be seen that the number of species is higher in all variants compared to the control. The highest average is in variant with $10 \mathrm{t} /$ ha manure (V2) whit $39.5 \%$ and the lowest is in variant with 100N50P50K (V6) where has only an average of $36 \%$ (Tab. 1).

The Shannon Index average is 2.489 which means this phytocenosis is reach in species. The value of a diversity index increases both when the number of types increases and when evenness increases.

Even if diversity does not differ very much, management practices (fertilization) strongly influence plant community. Hrevušová et al., in a study in 2009, show that the effect of long-term fertilisation on high-productive Alopecuretum grassland is still significant 17 years after its cessation. The residual effect of high nitrogen doses is indicated by the higher dominance of the high grasses group, mainly Holcus lanatus.

Other example is Păcurar 2005 when he show that Shannon index (index showing richness) while

\section{Floristic compositions}

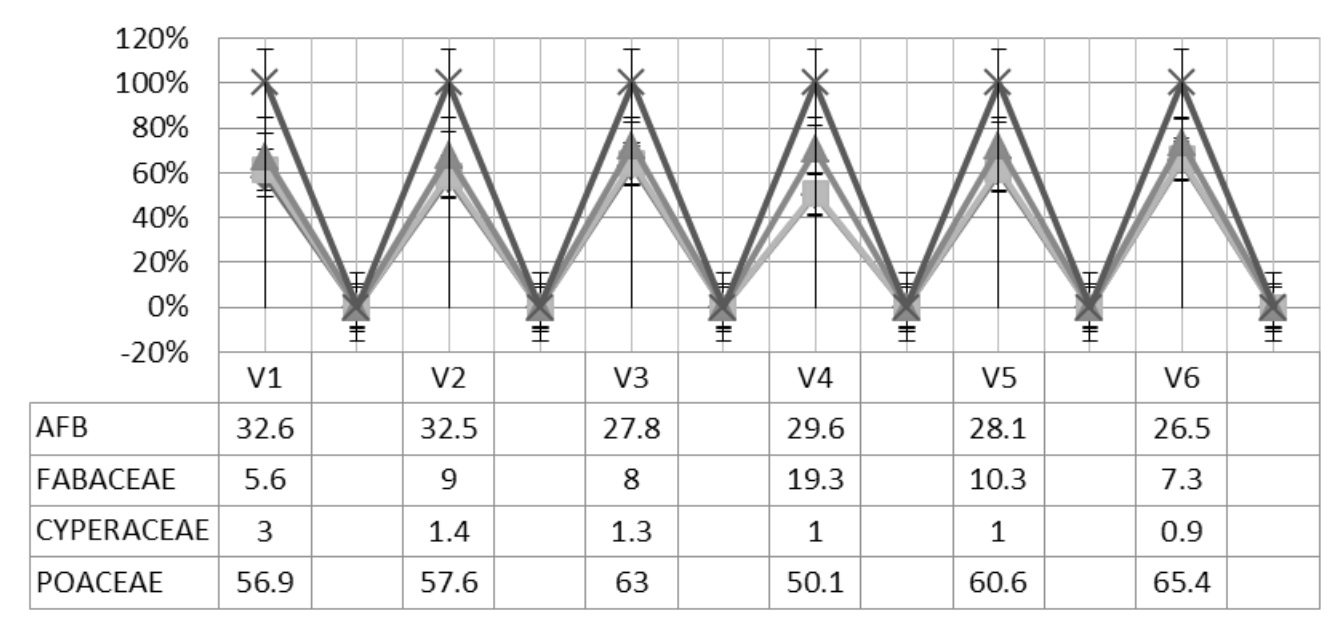

Fig. 1. Floristic composition of grassland on botanical family 
treatments applied decrease from 3.05 when natural grasslands at 2.62 at the application of 10 $\mathrm{t} /$ ha manure $+100 \mathrm{~N}: 50 \mathrm{P}: 50 \mathrm{~K}$. Inputs technology reduces biodiversity through extinction of vegetal cover the following species: Carex pallescens $L$, Arnica montana L., Cardaminopsis halleri L., Carlina acaulis L., Heracleum sphondylium L., Hypericum maculatum Crantz., Leontodon autumnalis $L$., Plantago lanceolata L., Plantago media L., Thymus pulegioides L., Tragopogon pratensis L. and Viola canina L.

Therefore, although the Shannon index is high after first experimental year, we believe fertilization will change the determined type of grasslands.

\section{CONCLUSION}

All treatments present differences when were compared to the control. Applied fertilizer produces changes in floristic composition and in diversity.

The difference in the floristic composition between organic fertilization and mineral fertilization after just one year is not recorded in our phytocenosis. We put this fact that the period was too short and this contributes to maintain plant diversity especially in mountain areas where traditional farming system has declined.

Acknowledgments. This paper was published under the frame of European

Tab. 1. Summary of the variants

\begin{tabular}{ccccc}
\hline Variants & $\mathrm{S}$ & $\mathrm{E}$ & $\mathrm{H}$ & $\mathrm{D}$ \\
\hline V1R1 & 34 & 0.698 & 2.462 & 0.8278 \\
\hline V1R2 & 33 & 0.721 & 2.520 & 0.8330 \\
\hline V1R3 & 33 & 0.719 & 2.515 & 0.8337 \\
\hline V1R4 & 30 & 0.697 & 2.370 & 0.8217 \\
\hline V2R1 & 35 & 0.678 & 2.410 & 0.8398 \\
\hline V2R2 & 43 & 0.702 & 2.640 & 0.8590 \\
\hline V2R3 & 41 & 0.706 & 2.621 & 0.8579 \\
\hline V2R3 & 39 & 0.692 & 2.535 & 0.8468 \\
\hline V3R1 & 32 & 0.684 & 2.372 & 0.8240 \\
\hline V3R2 & 37 & 0.695 & 2.508 & 0.8359 \\
\hline V3R3 & 34 & 0.699 & 2.465 & 0.8391 \\
\hline V3R4 & 38 & 0.679 & 2.472 & 0.8301 \\
\hline V4R1 & 38 & 0.703 & 2.556 & 0.8589 \\
\hline V4R2 & 37 & 0.739 & 2.669 & 0.8788 \\
\hline V4R3 & 34 & 0.735 & 2.591 & 0.8745 \\
\hline V4R4 & 38 & 0.712 & 2.590 & 0.8675 \\
\hline V5R1 & 37 & 0.675 & 2.436 & 0.8294 \\
\hline V5R2 & 38 & 0.663 & 2.413 & 0.8259 \\
\hline V5R3 & 34 & 0.673 & 2.374 & 0.8292 \\
\hline V5R4 & 38 & 0.672 & 2.446 & 0.8324 \\
\hline V6R1 & 40 & 0.669 & 2.468 & 0.8246 \\
\hline V6R2 & 36 & 0.699 & 2.505 & 0.8397 \\
\hline V6R3 & 36 & 0.677 & 2.424 & 0.8238 \\
\hline V6R4 & 32 & 0.687 & 2.381 & 0.8285 \\
\hline V35 & & & \\
\hline V3 & & & \\
\hline
\end{tabular}

Note: $\mathrm{S}=$ Richness $=$ number of non-zero elements in row

$\mathrm{E}=$ Evenness $=\mathrm{H} / \ln$ (Richness)

$\mathrm{H}=$ Diversity $=-\operatorname{sum}\left(\mathrm{Pi}^{*} \ln (\mathrm{Pi})\right)=$ Shannon`s diversity index

$\mathrm{D}=$ Simpson`s diversity index for infinite population $=1-\operatorname{sum}\left(\mathrm{Pi}^{*} \mathrm{Pi}\right)$

where $\mathrm{Pi}=$ importance probability in element $\mathrm{i}$ (element i relativized by row total) 
Social Fund, Human Resources Development Operational Programme 2007-2013, project no. POSDRU/159/1.5/S/132765.

\section{REFERENCES}

1. Baeten Lander, David I. Warton, Hans Van Calster, Pieter De Frenne, Gorik Verstraeten, Dries Bonte, Markus Bernhardt-Römermann, Johnny Cornelis, Guillaume Decocq, Ove Eriksson, Radim Hédl, Thilo Heinken, Martin Hermy, Patrick Hommel, Keith Kirby, Tobias Naaf, Petr Petřík, Gian-Reto Walther, Monica Wulf and Kris Verheyen. (2014). A model-based approach to studying changes in compositional heterogeneity. Methods in Ecology and Evolution Volume 5, Issue 2, pages 156-164,

2. Bianchia F.J.J.A., V. Mikosc, L. Brussaarda, B. Delbaere, M.M. Pullemana. (2013). Opportunities and limitations for functional agrobiodiversity in the European context. Environmental Science \& Policy Volume 27, Pages 223231

3. Braun-Blanquet, J. (1932) Pflanzensoziologie-Grundzüge der Vegetationskunde. Springer Verlag, Wien.

4. Hrevušová Z., Hakl J., Mrkvička J. and Martinek J. 2009. The dominance of high grasses and biomass production on
Alopecuretum after the cessation of long-term intensive fertilization. Grassland Science in Europe Vol 14, 391-393.

5. Mace GM, Collar NJ, Gaston KJ (2008) Quantification of extinction risk: IUCN's system for classifying threatened species. Conservation Biology 22: 1424-1442. doi: 10.1111/j.1523- 1739.2008.01044.x

6. Nilsson S. G., M. Franzén and L. B. Pettersson (2013). Land-use changes, farm management and the decline of butterflies associated with semi-natural grasslands in southern Sweden. Nature Conservation 6: 31-48 (2013), doi: 10.3897/natureconservation.6.520, http://www. pensoft.net/natureconservation

7. Stoie A. (2011). Cercetări asupra ecosistemelor de pajişti cu Arnica montana în bazinul superior al Arieşului. Teză de doctorat -USAMV Cluj- Napoca

8. Vázquez de Aldana B.R., Helander M., Zabalgogeazcoa I., García-Ciudad A., García-Criado B. and Saikkonen K. (2014) Interactive effects of Epichloë endophytes and plant origin on mineral content in Festuca rubra. Grassland Science in Europe, Vol. 19 - EGF at 50: the Future of European Grasslands, 184-186.

9. .***www.cdi.gov.ro 